\title{
Land Law Reform and Complex State-Building Process in Rwanda
}

\author{
Shinichi Takeuchi and Jean Marara
}

\begin{abstract}
This study sheds light on recent land law (land tenure) reform in Rwanda by examining its close and complex relations with state-building. By prioritising land law reform and receiving strong support from external funding agencies, the post-civil war Rwanda became the first African country to complete land registration throughout its territory. Land law reform should be considered a part of the radical interventions in rural areas frequently implemented by the Rwandan Patriotic Frontled government and, therefore, has been closely connected to its aspiration to reinforce the existent political order. The government has utilised reform and external financial support for this purpose. However, despite the success of the one-time land registration, Rwanda has encountered serious difficulties in institutionalising sustainable registering systems since transactions of land have been recorded only in exceptional cases. Additionally, it suggests that the government does not have a strong incentive to collect accurate information about properties in rural areas. The widening gap between recorded information and the real situation may affect land administration, which is of tremendous importance to Rwanda and, thus, possibly undermine state control over society.
\end{abstract}

Keywords Land registration $\cdot$ Rwanda $\cdot$ State-building $\cdot$ Land law reform

\section{Introduction}

As proposed in Chap. "Introduction: Drastic Rural Changes in the Age of Land Reform", recent land law (land tenure) reforms in Africa have had important and complex implications on politics and state-building. Rwanda is a representative case, as the country has utilised land law reform to consolidate the existent political order. The Rwandan Patriotic Front (RPF), which was a former rebel group and seized

\author{
S. Takeuchi $(\varangle)$ \\ African Studies Center, Tokyo University of Foreign Studies, Fuchu, Japan \\ e-mail: shinichi_takeuchi@tufs.ac.jp \\ J. Marara \\ Institut Catholique de Kabgayi, Muhanga, Rwanda
}


power by winning the civil war in 1994, undertook land law reform to strengthen its authority and control over society. Considering the Rwandan case study, this chapter indicates how the RPF-led government consolidated the political order through land intervention. Simultaneously, it also argues that the state-building process has never been simple.

With its origin tracing back to the precolonial kingdom, Rwanda has a long history of land intervention by the state. The precolonial state-building of the kingdom of Rwanda (Nyiginya) included land dominance by the king's families and the ruling class, which was mainly Tutsi (Vansina 2001). In the colonial period, chiefs and sub-chiefs, who were simultaneously landlords and officials of the colonial administration, attempted to expand their influence by providing land to their clients, thereby increasing competition and conflicts over land (Reisdorff 1952). Following the breakdown of chieftaincy during independence (Lemarchand 1970; Reyntjens 1985), the country was deprived of strong and autonomous local communities, thus accelerating state intervention in rural areas. Strong control of the political elites over rural societies explains in part the genocides in 1994 (Straus 2006). Since the power seizure by the RPF, the range and extent of such policy interventions in rural areas have significantly increased. Subsequently, land law reform has been an important component of these reforms. Due to this reform, which had strong financial support from donors, Rwanda became the first African country to complete land registration throughout its territory.

Although land registration in Rwanda has attracted considerable attention, assessments of its effects on land tenure security have been divided among researchers. World Bank researchers presented that land registration has enhanced the access of women (particularly legally married women) to land, thereby contributing to gender equality (Ali et al. 2014, 2017). The positive effects of land registration on gender equality were also confirmed by another study that analysed NGO projects (Santos et al. 2014). Conversely, other researchers have been sceptical and pessimistic on Rwanda's land law reform and the effects of land registration to secure the land rights of tillers (Pottier 2006; Ansoms 2008; Pritchard 2013; Ansoms et al. 2014; Huggins 2017). They argued that Rwanda's authoritarian policy implementation would have a negative impact on the security of property rights.

The following sections reveal that since the power seizure in 1994, the RPF-led government implemented multiple radical policy measures on land. These measures have not only drastically changed Rwandan rural society, but have also strengthened government control over land and society. The land law reform that was initiated in the mid-2000s has been a part of a series of radical interventions, through which efforts for state-building were undertaken.

However, the results have been diverse. This is particularly salient regarding land registration. Since it was strongly emphasised in the national land policy in 2004 (Republic of Rwanda 2004), land registration has been a top priority of the reform that was successfully completed by the country throughout its territory in 2013. However, the register has been updated only in exceptional cases of land transactions, including selling, purchasing, and inheritance, especially in rural areas. Consequently, the gap between the official information on the register and the real 
situation has been increasingly widening. Although the country successfully implemented a big project of one-time land registration, it faced serious difficulties in constructing an institution for its sustainable management. What are the reasons for this stark contrast and what are its implications for Rwandan state-building? The present chapter attempts to answer these questions.

The remainder of this chapter is organised as follows. Following a brief explanation of the methodology, a rough historical overview of the relationship between land and state-building in Rwanda is provided before presenting a detailed explanation of Rwanda's land law reform. Later, policy interventions in rural areas under the RPFled government are examined to investigate its motivations for undertaking land law reform. Finally, the successes and setbacks of the land registration are illuminated to explore its implications.

\section{Methodology}

This study is based on multiple literature surveys and field observations of the authors. One of the two authors (Marara) observed Rwanda daily, while the other author (Takeuchi) visited the country for the first time in 1998, and launched collaborative research with Marara, focusing on two rural communities in Southern and Eastern Provinces. After conducting a socio-economic questionnaire survey for approximately 100 households in each community (Takeuchi and Marara 2000), 25 inhabitants (respondents of the former survey) from each community were selected for conducting interviews through semi-structured questionnaires. However, the death of some respondents and addition of new respondents in accordance with our research aims changed the number of interviewees. While such interviews sometimes included administrative officers and leaders of cooperatives, unofficial discussions and observations in the communities were frequent in multiple cases. This constituted indispensable background information for understanding the perspectives of people to the policy reforms.

\section{The Rwandan State and Land Before the Civil War}

The origin of the precolonial kingdom of Rwanda can be traced back to the seventeenth century, and its state formation process was characterised by the expansion and the strengthening of control over land. In the early nineteenth century, the ruling class of the kingdom (majorly Tutsi), which was mainly dependent on pastoralism, began to subjugate peasants (majorly Hutu) by imposing tributes based on land control (Vansina 2001). This Tutsi-Hutu division gradually widened and was institutionalised during the colonial period. Under indirect rule, the king's power was reinforced by the support of the colonial authority. During political stabilisation, the chiefs and sub-chiefs, who were overwhelmingly Tutsi, actively provided land to their 
clients to seek their dominance (Reisdorff 1952). Therefore, in the state-formation process of the kingdom, intervention in land constituted an essential part.

Traditional Tutsi leaders, such as kings, chiefs, and sub-chiefs, who had once monopolised political power in the colonial period, had completely lost their influence following the social revolution, which started in 1959 (Lemarchand 1970; Reyntjens 1985). The kingdom collapsed and the Hutu-led party, PARMEHUTU (Parti $d u$ mouvement de l'émancipation Hutu), seized power. Because of this political development, Hutu lower officials actively intervened in rural lands. Appointed by the ruling parties, the PARMEHUTU and the MRND (Mouvement républicain national pour le développement) under the Kayibanda (1962-1973) and Habyarimana (19731994) regimes, respectively, often reallocated the land left by Tutsis who had fled from Rwanda for the sake of poor landless Hutu farmers (André and Lavigne Delville 1998).

During this period, Rwanda's population density was already high, thus, causing land scarcity and de facto privatisation (Blarel 1994). However, similar to other African countries, the Rwandan state attempted to strengthen its control over customary land by claiming its official property rights. Additionally, it banned the trade of customary land, although such deals were widely practised unofficially (André 2003). Whereas this incident demonstrated the weak implementation capacity of the government, the absence of chieftaincy facilitated the government to implement policy interventions in rural areas. In fact, Rwanda has witnessed multiple state-led rural development projects during this period(Boone 2014, 229-252).

\section{Land Law Reform in Rwanda}

The 2004 land policy marked the beginning of the recent land law reform in Rwanda. The new constitution was ratified in 2003, nine years after the end of the civil war. The adoption of the new land policy in the year following the promulgation of the constitution indicated that land was one of the most urgent priorities for the RPF-led government. A keen sense of crisis regarding land and agriculture characterised the 2004 land policy. During its introduction, nine 'obstacles' hindering 'the efficient management of land in Rwanda' were pointed out: rapid population growth, low technological use in agriculture, customary land tenure system, multiple landless people, scattered farming plots, lack of a land registration system, absence of landuse planning, chaotic land transactions, and unplanned use of marshlands (Republic of Rwanda 2004, 5). Among these, the first five 'obstacles' could be interpreted as the causes of the crisis, and the last four as possible solutions. To summarise, to tackle Rwanda's structural problems, including population pressure, land scarcity, and land fragmentation, the policy proposed enhancing efficient land use through the development of the land market. Additionally, land registration and land-use planning were prerequisites for this purpose.

The necessity of land registration was frequently emphasised in the 2004 land policy. One of its key concepts was 'land administration', which was defined as 'the 
process of registration and dissemination of information in relation to land titles and all sorts of land transaction, as well as the use of land-linked natural resources' (Republic of Rwanda 2004, 30). The policy argued that good 'land administration' secured land rights, levied land tax, provided collaterals, activated land transaction, reduced land conflicts, and improved infrastructure development. Emphasised as a central piece of the 'land administration', land registration was prioritised in the 2004 land policy.

The 2005 land law, which was designed based on the 2004 land policy, provided policy frameworks not only for land, but also for agriculture and rural development. Although it covers a wide range of policy areas, the following three points are particularly important and deserve to be mentioned.

First, the law recognised customary rights by committing to protect 'equally the rights over the land acquired from custom and the rights acquired from written law' (article 7). Although private use of customary lands was generally practised even before the enactment of the 2005 land law, this had no legal framework. The 2005 land law officially recognised customary rights as grounds for registration. Second, land registration was mandatory (article 30). This provision clearly corresponded to the 2004 land policy. Third, the law introduced various measures to enhance the efficiency of land use. By compelling landowners and land users 'to obey laws and regulations relating to protection, conservation and better exploitation of the land' (article 60), the law authorises the government to requisition the land that is not "well managed and productively exploited' (article 73). Similarly, to improve rural land productivity, the law promoted the 'consolidation of small plots of land', prohibited 'to reduce the parcel of land reserved for agriculture of one or less than a hectare' (article 20), and obliged to make 'the area's master plan' (artcle 63). These regulations aim at boosting land productivity through putting together small plots, avoiding land fragmentation, and controlling the land use.

Since then, regulations and rules adopted in the 2005 land law have been rigorously implemented. Following a pilot project, the Rwanda Natural Resource Authority (RNRA) undertook a systematic land registration project from 2009 and built a digital database of 10.4 million plots in the Rwandan territory, with information about their borders and owners (Sagashya and English 2010, 64; Innovations for Successful Societies 2017, 4). In rural areas, people's customary rights were recognised as they were, and certificates were automatically distributed for every plot at a relatively reasonable charge. ${ }^{1}$ Following multiple measures for raising awareness about the importance of titles and for facilitating their take-up, 7.16 million out of 8 million certificates that had been printed by the RNRA were handed over to owners as of June 2017 (Innovations for Successful Societies 2017, 18). Importantly, the certificates provided following the registration were issued in the form of 'emphyteutic leases', namely, long-term leases, available for up to 99 years on agricultural lands and 20-49 years on other land types.

\footnotetext{
1 The commission for issuing land certificates was 1000 Rwandan Francs (Frw) per plot. The amount was equivalent to US\$1.8 according to the exchange rate in 2009 .
} 
In addition to land registration, several measures have been implemented for efficient land use. For instance, through land-use planning, which was mandatory for every district, ${ }^{2}$ the distinction between residential and cultivation areas was clarified. Consequently, the local administration demanded people to use land according to the distinction and urged them to live in residential areas. As Rwandans had no tradition to live in gatherings, their dwellings had been scattered on the hills. In this context, the government utilised land-use planning to promote its villagisation policy, which was adopted immediately after the end of the civil war, but was gradually implemented. Subsequently, people have increasingly moved to residential areas under governmental pressure. ${ }^{3}$

The land consolidation policy, which constitutes a major part of the crop intensification programme (CIP), is another measure that has vast impacts on Rwandan agriculture and rural societies, promoting the cultivation of six selected food crops (maize, wheat, rice, potato, bean, and cassava) by distributing their improved seeds and chemical fertilisers. ${ }^{4}$ In areas where land consolidation policy has been implemented, farmers are required to cultivate the same crop promoted by the government. This policy has been majorly implemented in marshlands, which are owned by the government; subsequently, only members of cooperatives are allowed to cultivate in these areas. ${ }^{5}$ As a result, production of some food crops has rapidly increased since then (Fig. 1). ${ }^{6}$ Presently, the government intends to expand areas under the land consolidation policy from marshlands to hills.

Although certificates were distributed to every landowner, the registration did not aim at establishing private property rights. The delivered certificates were in the form of long-term leases and, therefore, effective for a limited period. Thus, the state can theoretically confiscate lands that were not 'productively exploited' ${ }^{7}$ indicating that

\footnotetext{
2 Rwandan local administration includes four provinces and Kigali city, 30 districts, 416 sectors, 2148 cells, and more than 14,000 Imidugudu, which is the smallest local administrative unit with no paid official.

${ }^{3}$ See Newbury (2012), and the authors' observation in Southern Province.

${ }^{4}$ The distribution has been handled by cooperatives. In its early stage, the government provided subsidies to encourage farmers to use improved seeds and chemical fertilisers at a low price; however, the subsidy was later reduced.

${ }^{5}$ Historically, marshlands in Rwanda were used as pasture only in the dry season, and the colonial government started their development and conducted drainage. For this historical reason, the land rights of those land parcels were given to those who began to use first, although they legally belonged to the state. However, the control of the marshland has been remarkably strengthened since the enactment of the new land law, as the government announced that only members of registered cooperatives could cultivate marshlands.

${ }^{6}$ Rwanda's food production index (average 2004-2006 = 100) was 155 in 2014, significantly exceeding the average of sub-Saharan countries, which was 132, in the same year. The CIP undoubtedly contributed to this increase. See also Huggins (2017).

${ }^{7}$ According to the authors' observations, requisition of lands has not been rigorously implemented. Besides the participation in the strictly monitored land consolidation, land use of each field has not been carefully examined. Although we do not know if the lack of strict monitoring should be considered as a deliberate policy or a mere limit of administrative capacity, we can assume that the provision of the 2005 land law has not been literally implemented to this point.
} 


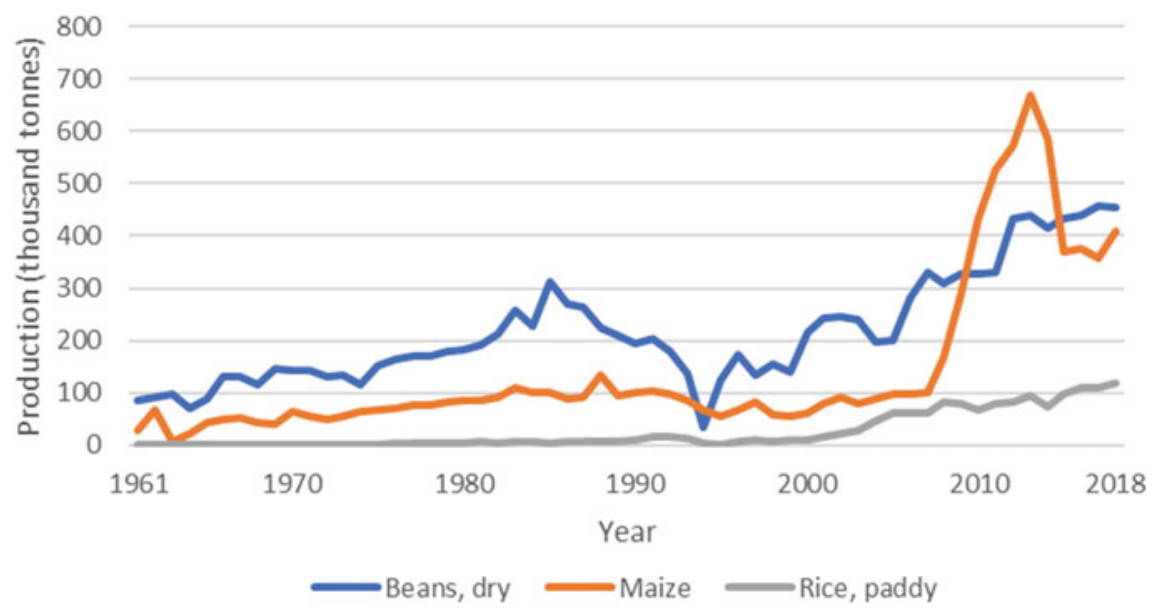

Fig. 1 Production of targeted food crops in Rwanda. Source FAOSTAT

the law has given the state strong powers to closely monitor and control land use more effectively, since the state has urged people to live in residential areas and imposed a limited number of food crops under the CIP.

\section{Context of Land Law Reform in Rwanda}

Adoption of the land policy in 2004 and the enactment of the new land law in 2005 were undoubtedly important events for the Rwandan government to strengthen its intervention in land. However, the intervention did not start abruptly with the land policies. As mentioned earlier, political interventions on land trace back to the precolonial period in Rwanda. Additionally, RPF, which won the civil war in the 1990s, implemented multiple radical measures on land immediately after the establishment of the government.

Although the RPF was originally organised by the second generation of Tutsis expelled through the social revolution, they never attempted to revitalise the Tutsiled chieftaincy. Rather, they implemented measures immediately after their power seizure that served as a land provision policy for Tutsi returnees. This is called 'land sharing'(Bruce 2009; Huggins 2009; Leegwater 2011; Musahara and Huggins 2005; Takeuchi and Marara 2014). The RPF's victory during the civil war in 1994 resulted in the increased return of Tutsi refugees ('old returnees') who had previously stayed abroad. On their arrival in Rwanda, the old returnees occupied vacant lands and houses, particularly in the eastern part of the country, following administrative instructions. This was possible with ease because the RPF's power seizure caused the mass exodus of Hutu inhabitants into neighbouring countries, particularly the Democratic Republic of the Congo (at the time, Zaïre; hereafter, Congo) 
and Tanzania. However, conflicts arose when the Hutu refugees began to repatriate following the beginning of war in the eastern Congo in 1996 because these "new returnees' found their lands and houses occupied by the old returnees.

Under the land-sharing policy, the new returnees had to hand over half of their lands to the old returnees. This policy had a clear objective of ensuring land ownership for the old returnees, who had returned to Rwanda after several decades. It was a radical measure because it ensured land ownership for the old returnees to the detriment of the new returnees. While the Rwandan government has defended the policy for tackling the lack of land ownership (Republic of Rwanda 2004, 27), it evidently had a more specific focus. Since the old returnees were strong supporters of the RPF, land sharing evidently aimed at strengthening the political basis of RPF by providing land for their supporters. Although the policy came as a shock and led to deep dissatisfaction among the new returnees, such resentment did not result in political instability that could jeopardise the hegemony of the RPF. The military victory of RPF in the civil war and its subsequent authoritarian governance did not create a political position in Rwanda for any effective opposition movement, thus enabling the ruling party to suppress criticism.

The government has consistently undertaken efforts to provide legal support for land sharing. Overwhelming cases of land sharing in the late 1990s were urged by administrative guidance, but lacked legal basis. However, the 2005 land law recognised that beneficiaries of land sharing 'shall enjoy the same rights as those under customary holdings' (article 87). Subsequently, its modalities were officially fixed in a ministerial order in $2010 .{ }^{8}$ Although it was legalised after more than a decade, an overwhelming majority of land sharing had actually already occurred, indicating the eagerness of the Rwandan government for providing official recognition to land sharing. Land registration was completely aligned with this stance since it reinforced the legality of land sharing by providing official certificates. By placing the understanding of land registration in the context of RPF's frequent interventions in land, the policy aligned well with its agenda of territorial control.

In addition to land sharing, the post-civil war Rwanda witnessed multiple radical interventions in its rural and agricultural sectors. Revision of the civil code in $1999^{9}$ significantly influenced Rwandan rural societies because it recognised the rights of women to inherit land. Rwanda has been a patriarchal society, where women have been excluded from land inheritance. However, the law adopted in 1999 clearly advocated gender equality for inheritance. Although the law confined equality among children of legitimate marriage, it undeniably brought radical changes in rural societies, which effectively implemented the law. Currently, the inheritance of land to daughters is commonly observed in rural areas, contrary to what was observed two decades ago. ${ }^{10}$ The RPF attitude, which substantially influenced the administration

\footnotetext{
${ }^{8}$ Ministerial Order No 001/16.01 of 26/04/2010. 'Ministerial Order determining the modalities of land sharing'.

${ }^{9}$ Law No 22/99 of 12/11/1999 to supplement book I of the Civil Code and to institute part five related matrimonial regimes, liberalities, and successions. OG no 22 of 15/11/1999.

10 The effects of the legalisation of inheritance of land on women without legitimate marriage are still unclear. Based on the pilot survey conducted in 2010, Ali et al. (2014) argued that Rwanda's
} 
and the judiciary, significantly resulted in this change. Since the ruling party regularly supported women's equal rights of inheritance, this principle has been strictly regarded in the administration and judiciary.

Furthermore, the campaign against thatched roofs was also another radical policy (Ingelaere 2014). A presidential speech had blamed thatched roofs for insanitary conditions; consequently, multiple dwellings with thatched roofs were destroyed during the campaign conducted in 2011. The authors observed that many villagers in the study site were suddenly instructed by the executive secretary (the only formal official receiving a salary in the cell) to remove their thatched roofs. A couple of weeks later, the executive secretary personally inspected every household in the cell and ordered young male collaborators to remove and destroy any remaining thatched roofs. However, although the executive secretary promised that a tin roof would be provided in compensation for the destroyed thatched roofs, its implementation and provision either took several months, or the promise was never fulfilled. The case shows that policy interventions that aimed at modernising the rural and agricultural sectors have been compulsory and violently executed. Thus, since its establishment, the RPF-led government has regularly brought about radical policy interventions, including land law reforms.

The government's motivations for taking these radical policies may not be understood simply by the partisan interests of the RPF. ${ }^{11}$ Rather, it shows that the ruling party had a strong will and mission to restructure and modernise Rwandan rural society. Scholars have already indicated the RPF's ambition in rural engineering (Newbury 2012; Behuria 2015; Huggins 2017). For instance, Ansoms argued that the RPF regime, whose core members grew up in foreign refugee camps and, therefore, had only tenuous connections with Rwandan rural society, considered the existing social norms and agricultural technologies as outdated. Therefore, they undertook radical measures for modernisation from the elitist viewpoints (Ansoms 2009).

Rather, the authors consider that the RPF's desire for social engineering originated from a strong sense of crisis. As seen in the previous section, given serious land shortages and agricultural stagnation, RPF considered the socio-economic modernisation of Rwandan rural societies as inevitable. Additionally, Chemouni emphasised the importance of the vulnerability of the RPF elites in explaining the radical measures implemented for decentralisation in Rwanda. He insisted that the sense of vulnerability 'is particular by its intensity as it reaches not only mere political survival, but

\footnotetext{
land tenure reform resulted in 'significant reduction of the probability of having documented land ownership' for women who were not legally married (Ali et al. 2014, 272). Although another paper published three years later evaluated that the 'inclusion of women in informal marriages were effective' (Ali et al. 2017, 379), it did not provide any compelling evidence. The authors observed that the name of the second wife in the certificates were described with her husband's name, but whether this case is exceptional or typical is unknown. Considering that polygamy is illegal in Rwanda, the risk of tenure insecurity for women in informal marriages by legalisation of land rights is highly possible.

11 The imihigo (performance contract) between the superiors and the subordinates in the administration undoubtedly explains the reasons for implementing radical policies, but it does not explain why the government chose such radical policies. Regarding imihigo, see Chemouni (2014).
} 
also the physical security of the elite' (Chemouni 2014, 255). Social engineering has been a measure of power consolidation and a result of vulnerability (Doner et al. 2005), which is an important part of the RPF's sense of crisis.

The argument in this section shows that Rwanda's land law reform should be understood in the context of its active interventions in rural societies in the post-civil war period. As a tool of social engineering, the reform has been motivated by the desire not only to improve agricultural productivity, but also to sustain and reinforce the current political order. In other words, modernisation of rural society has been pursued under the condition that the RPF-led political order should be reproduced. Land law reform therefore, is significant for the state-building project that the RPF has been conducting since 1994 .

\section{Mixed Results of the Land Registration Project}

Has the land law reform contributed to RPF-led state-building? Apparently, the answer seems to be 'yes', but the reality is not so straightforward. Following the enactment of the 2005 land law, Rwanda quickly registered land throughout its territory. The operation was undoubtedly technically and financially assisted by donors, ${ }^{12}$ but the remarkable speed for accomplishing the registration indicated the willingness and effectiveness of the Rwandan administration.

However, the results of land registration are diverse. Land registration has evidently brought some improvements. For instance, the provision of a certificate, which distinctly indicates the shape and position of a parcel, has reduced conflicts over borders. Additionally, another effect is the increase in activities in the mortgage market promoted by the ease of using land as collateral (Ali et al. 2017, 380).

Conversely, the project encountered great difficulties in updating the data on land tenure. Due to the land registration project, people were provided with their respective land certificates even in remote areas. However, changes in the land registration data because of selling, buying, and inheritance have been recorded only in exceptional cases, thereby increasing the gap between the registered information and the real situation. This gap was particularly evident in rural areas. The author encountered many farmers who had sold or bought parcels, but none of them had updated their certificate. A study conducted by World Bank researchers corresponded to the authors' observations. The national database and the survey data of this study revealed that among the 31,209 transactions of residential land recorded in 2014 and 2015, only $6.23 \%$ in Kigali city and $0.33-0.93 \%$ in the four provinces were registered. Regarding the 22,850 transactions of agricultural land, only $1.67 \%$ of the land in Kigali city and $0.06-0.23 \%$ in the four provinces were registered (Ali et al. 2017,

\footnotetext{
12 Of the total budget of the land tenure regularisation project up to end of July 2013 ( $£ 42,206,324)$, the government of Rwanda contributed less than $10 \%(£ 3,912,939)$. See Gillingham and Buckle $(2014,20)$.
} 
384). Thus, the infrequent updating of the register is a critical problem, endangering the central pillar of land administration.

The extremely low rate of updating was explained by the following two important factors. First, the cost of updating is identical throughout the territory; thus, it is too expensive for ordinary people, particularly in rural areas. In addition to 27,000 Frw as the commission for the new issuance of a land certificate (Ali et al. 2017, 382), those who request updating and reissuing have to cover additional expenses, including transport fees for surveyors. ${ }^{13}$ In the case of the division of a parcel, a commission is charged for each new certificate, thus making the official procedure too expensive and practically impossible for ordinary rural people. Second, dividing a parcel of 1 ha or less was banned by article 20 of the 2005 land law. Due to the general land shortage, only a few Rwandans have parcels larger than 1 ha. ${ }^{14}$ According to statistics, the average size of landholding per household was 0.76 ha and $80 \%$ of the size of landholding per household fell into the category of less than 1 ha (Republic of Rwanda 2010, 36). In most cases of inheritance and deals, the size was not sufficiently big to be officially divided, thus resulting in people to engage in unofficial transactions.

Additionally, the registration of family land made official land divisions more complex. After the initiation of official registration in 2009, Rwanda quickly completed the demarcation and adjudication of the whole country. One of the factors contributing to this rapid completion was that land registration was not only recognised through an individual, but also through a family (Takeuchi and Marara 2014, 94). During the registration process, people could register a plot under the name of a deceased father or grandfather, thus enabling their children or grandchildren to be entitled to a land without individually demarcating it. ${ }^{15}$ People appreciated this method. Besides reducing the expense of issuing land certificates, it also shelved complicated debates over inheritance among family members. Furthermore, this was expedient for the government, which depended on foreign aid for the land registration project. As this method eliminated the obstacles for registration, the project was completed in a short duration before the aid was exhausted.

However, now this is one of the reasons for the increase in unofficial transactions. Restoring land rights for each individual is the most difficult challenge in the transition from a system based on customary land tenure to that based on modern land registration (Coldham 1978). Rwanda could address this challenge by registering the entire family land without distinguishing individual plots. However, in reality, it simply deterred the problem inevitably posed by inheritance. The division of family

\footnotetext{
${ }^{13}$ Information collected from multiple respondents during fieldwork in August 2015 and August 2016. The average exchange rate of Rwandan francs to a US dollar in 2015 was 720.98 (calculated from the data of the IMF, International Financial Statistics). 27,000 Frw was around US\$37.

14 After the initiation of registration in 2009 , land certificates were provided for all land plots, including those smaller than 1 ha.

15 The registration of family land under the name of a deceased person is indicated in the certificate as a 'succession'. For instance, an indication of 'succession Rwakairo' as the title holder means that the plot belongs to the children of the late Rwakairo.
} 
lands has emerged as a serious issue in rural areas. Once land has been registered, officially dividing it is nearly impossible. In addition to the above-mentioned obstacles, building consensus among family members has been difficult. Currently, banks and cooperatives refuse to accept a parcel registered by a deceased person as collateral. ${ }^{16}$ In rural areas, many people have complained of the inability to officially divide the land for inheritance or sell the land.

Today, in Rwanda's rural areas, parcels are generally transferred without any official procedure for updating the register. In the case of land trade, a handmade memo mentioning its shape and size along with the signatures of witnesses is prepared as a proof, similar to the procedure that was followed by people before the implementation of land registration (André 2003). Such unofficial dealings cause dissatisfaction because it provides and assures weak legal rights. For instance, parcels without official certificates cannot be used as collateral for financing. Additionally, people are aware that in the case of an expropriation, compensation will not be paid for a plot without a certificate. ${ }^{17}$ In fact, a serious dilemma exists: although they cannot afford to meet the huge expenses for the official updating of land certificates, they are compelled to divide lands either to raise money for their daily living or for inheritance. Therefore, unofficial land deals have increased.

Although Rwanda has completed land registration throughout its territory, the system has become stagnant as updating has been conducted for only exceptional cases. Despite the recognition of this issue by the government, ${ }^{18}$ no effective measures have been implemented so far to address it. Recognition of the issue in the revised national land policy in 2019 was a positive step (Republic of Rwanda 2019, 27), but concrete measures have not yet been proposed. The government's slow response has been contrasting with the take-up problem, which was revealed following the preparation of the land certificates. When the RNRA realised that land certificates were not being collected, it promptly undertook multiple effective measures to facilitate quick take-up of the certificates (Innovations for Successful Societies 2017, 8-15). Considering that accurate land registration is a prerequisite for effective land administration, to which Rwanda's land policy attaches cardinal importance, the current situation may be serious.

Political inertia can be explained by the weak pressure on the government to improve the situation. ${ }^{19}$ Two important reasons can provide suitable explanation.

\footnotetext{
${ }^{16}$ Interview at a village in Southern Province conducted on 24 February 2018.

${ }^{17}$ In an area near our study site in Southern Province, a land expropriation was performed for the construction of a military camp. The interviewees were aware that parcels without certificates would not be compensated in case of expropriation (interviews in February 2018).

18 This problem has been already highlighted by consultants and researchers. See Innovations for Successful Societies, 2017 and Ali et al. (2017). In addition, the pro-government newspaper commented on the expensive cost for updating based on research conducted by INES-Ruhengeri. See New Times, 'Land transaction fees too high, says new survey', 27 June 2015.

${ }^{19}$ Although during our interviews we raised this issue with officers in the local administration, they were generally indifferent to this problem. They attributed the reason of non-updating to the lack of public awareness and general ignorance of rural inhabitants rather than the cost (our interview in September 2019).
} 
First, land-related taxes do not constitute an important source of Rwandan revenue. Currently, the first 2 ha of agricultural land are exempted from taxes. ${ }^{20}$ As we have argued previously, few people possess lands larger than 2 ha, and the majority of landholders in rural areas pay no land tax. As the government does not depend on land tax, it has little incentive to provide accurate information about land tenure. ${ }^{21}$ Goodfellow points out that Rwanda's state revenue barely depends on land-related taxes than on the experience in Asian developmental states (Goodfellow 2017). He suggests the reason as '[a]n aversion to disrupting what has thus far been a relatively untouched sphere of elite capital accumulation' (Goodfellow 2017, 564). Second, the Rwandan land and property regime has an excellent reputation among the international community. Among the World Bank 'Doing Business' indices, 'Registering Property' places Rwanda in the third highest position in the world after Qatar and New Zealand. ${ }^{22}$ The index explains that the evaluation is based on the administrative procedures regarding property, including its purchase, transfer, and use as collateral, and the quality of land administration. ${ }^{23}$ It does not take into account that information about land registration has been updated only exceptionally in the country. In a bid to attract foreign capital, Rwanda placed high importance on the bank's indices and made efforts to improve it. If the index overestimates the Rwandan land registration system, the country has no pressure to change.

\section{Conclusion}

Although closely intertwined, two main objectives have been identified regarding interventions in land by the state. The first objective is resource management. The state holds strong interests in intervening in land because the land includes vital resources, and their appropriate management is critical for its own survival. The other objective is territorial control. ${ }^{24}$ It is imperative for the modern state to establish a political order in its territory. Both colonial states and independent African states had keen interests in restoring their authority with people living within the territory. Although land policies are concerned with resource management, the major hidden intentions are concerned with the regulation of state power. In the post-conflict Rwanda, the RPF-led government pursued these two objectives through multiple

\footnotetext{
${ }^{20}$ Republic of Rwanda, 2019 National land policy, p. 28.

${ }^{21}$ This contrasts with land tax reform conducted in the early stage of modernisation in Japan. The reform initiated in 1877 to gather accurate information about land tenure and issuing certificates for all landowners was one of the first attempts for modernising the tax system, which was prioritised by the new Meiji government. It was considered crucial, as the government heavily depended on land taxes. See Sasaki (1989, ii).

22 www.doingbusiness.org/en/rankings (accessed 10 March 2021).

${ }^{23}$ Regarding the methodology, see www.doingbusiness.org/en/methodology/registering-property (accessed 10 March 2021).

${ }^{24}$ The idea that two objectives are identifiable in the state intervention in land has been inspired by Lund (2013).
} 
radical interventions in land, increasing agricultural productivity and strengthening the political order. Radical policy interventions in rural societies in general, and land in particular, can be considered as an essential part of the state-building project in post-conflict Rwanda.

The present complex process of land registration indicates the difference in intention of the Rwandan government and the financial and technological donors. Although one-time land registration was successfully completed with huge assistance from donors, establishing a sustainable land registration system faces serious difficulties. The donors eagerly assisted the project because they presumed that fixing property rights would be a prerequisite for economic development (de Soto 2000). Conversely, Rwanda had a strong incentive to undertake land registration to stabilise political order and strengthen the state control over land. While the two parties had the same interests in completing the registration quickly, Rwanda did not have any additional incentives to institutionalise a functioning registration system, mainly because its revenue does not heavily depend on land and property taxes, and donors have continuously encouraged the country's current property system.

These reasons indicate the close linkage of state-building with external actors. Undertaking land registration is quite unusual for a country whose revenue does not depend on land taxes. Historically, land registration has been initiated at the government's request to modernise and rationalise tax collection. However, this is not observed in recent land law reforms in Africa because they are often led by the international community on the assumption that land registration will reinforce tillers' rights and enhance economic development. Rwanda's experience indicates that a reform driven by external actors is possible only if the intentions of the recipient country support it. While the country strengthened its control over land and territory through one-time land registration, the widening gap between the available information and the real situation may affect land administration and, thus, possibly undermine state-building.

Acknowledgements This work was supported by JSPS KAKENHI Grant Numbers 16H06318, 16KT0046, 18H03439, 18H03621, 18H03624, 19KK0031.

\section{References}

Ali, D.A., K. Deininger, and M. Goldstein. 2014. Environmental and gender impacts of land tenure regularization in Africa: Pilot evidence from Rwanda. Journal of Development Economics 110: 262-275. https://doi.org/10.1016/j.jdeveco.2013.12.009.

Ali, D.A., K. Deininger, and M. Duponchel. 2017. New ways to assess and enhance land registry sustainability: Evidence from Rwanda. World Development 99: 377-394. https://doi.org/10.1016/ j.worlddev.2017.05.016.

André, C. 2003. Custom, contracts, and cadastres in north-west Rwanda. In Securing land rights in Africa, ed. T.A. Benjaminsen and C. Lund, 153-172. London: Frank Cass. 
André, C. and P. Lavigne Delville. 1998. Changements fonciers et dynamiques agraires: le Rwanda, 1900-1990. In Quelles politiques foncières pour l'Afrique rurale? Réconcilier pratiques, légitimité et légalité, ed. P. Lavigne Delville, 157-182. Paris: Karthala.

Ansoms, A. 2008. A green revolution for Rwanda? The political economy of poverty and agrarian change. Institute of Development Policy and Management Discussion Paper 41, University of Antwerp.

Ansoms, A. 2009. Re-engineering rural society: The visions and ambitions of the Rwandan elite. African Affairs 108 (431): 289-309. https://doi.org/10.1093/afraf/adp001.

Ansoms, A., G. Cioffo, C. Huggins, and J. Murison. 2014. The reorganization of rural space in Rwanda: Habitat concentration, land consolidation and collective marshland cultivation. In Losing your land: Dispossession in the Great Lakes, eds. A. Ansoms and T. Hilhorst, 163-185. Suffolk: James Curry.

Behuria, P. 2015. Between party capitalism and market reforms: Understanding sector differences in Rwanda. The Journal of Modern African Studies 53 (3): 415-450. https://doi.org/10.1017/S00 $22278 X 15000403$.

Blarel, B. 1994. Tenure security and agricultural production under land scarcity: The case of Rwanda. In Searching for land tenure security in Africa, ed. J.W. Bruce and S.E. Migot-Adholla, 71-95. Washington, DC: World Bank.

Boone, C. 2014. Property and political order in Africa: Land rights and the structure of politics. Cambridge: Cambridge University Press.

Bruce, J.W. 2009. International standards, improvisation, and the role of international humanitarian organizations in the return of land in post-conflict Rwanda. In Uncharted territory: Land, conflict and humanitarian action, ed. S. Pantuliano, 109-131. Rugby: Practical Action Publishing.

Chemouni, B. 2014. Explaining the design of the Rwandan decentralization: Elite vulnerability and the territorial repartition of power. Journal of Eastern African Studies 8 (2): 246-262. https://doi. org/10.1080/17531055.2014.891800.

Coldham, S. 1978. The effect of registration upon customary land rights in Kenya. Journal of African Law 22 (2): 91-111.

de Soto, H. 2000. The mystery of capital: Why capitalism triumphs in the West and fails everywhere else. New York: Basic Books.

Doner, R.F., B.K. Ritchie, and D. Slater. 2005. Systematic vulnerability and the origins of developmental states: Northeast and Southeast Asia in comparative perspective. International Organization 59 (2): 327-361.

Gillingham, P. and F. Buckle. 2014. Rwanda land tenure regularisation case study. HTSPE limited for Evidence on Demand.

Goodfellow, T. 2017. Taxing property in a neo-developmental state: The politics of urban land value capture in Rwanda and Ethiopia. African Affairs 116 (465): 549-572. https://doi.org/10. 1093/afraf/adx020.

Huggins, C. 2017. Agricultural reform in Rwanda: Authoritarianism, markets, and zones of governance. London: Zed Books.

Huggins, C. 2009. Land in return, reintegration, and recovery processes: Some lessons from the Great Lakes Region of Africa. In Uncharted territory: Land, conflict and humanitarian action, ed. S. Pantuliano, 67-93. Rugby: Practical Action Publishing.

Ingelaere, B. 2014. What's on a peasant's mind? Experiencing RPF state reach and overreach in post-genocide Rwanda (2000-2010). Journal of Eastern African Studies 8 (2): 214-230. https:// doi.org/10.1080/17531055.2014.891783.

Innovations for Successful Societies. 2017. Securing land rights: Making land titling work in Rwanda, 2012-2017. Global Challenges Certification.

Leegwater, M. 2011. Sharing scarcity: Issues of land tenure in south-east Rwanda. In Natural resources and local livelihoods in the Great Lakes Region of Africa: A political economy perspective, ed. A. Ansoms and S. Marysse, 104-122. Basingstoke: Palgrave Macmillan.

Lemarchand, R. 1970. Rwanda and Burundi. London: Pall Mall Press. 
Lund, C. 2013. The past and space: On arguments in African land control. Africa 83 (1): 14-35. https://doi.org/10.1017/S0001972012000691.

Musahara, H. and C. Huggins. 2005. Land reform, land scarcity and post-conflict reconstruction: a case study of Rwanda. In From the ground up: Land rights, conflict and peace in Sub-Saharan Africa, eds. C. Huggins and J. Clover, 269-346. Pretoria: Institute for Security Studies.

Newbury, C. 2012. High modernism at the ground level: The imidugudu policy in Rwanda. In Remaking Rwanda: State building and human rights after mass violence, ed. S. Straus and L. Waldorf, 223-239. Madison: University of Wisconsin Press.

Pottier, J. 2006. Land reform for peace? Rwanda's 2005 land law in context. Journal of Agrarian Change 6 (4): 509-537. https://doi.org/10.1111/j.1471-0366.2006.00133.x.

Pritchard, M.F. 2013. Land, power, and peace: Tenure formalization, agricultural reform, and livelihood insecurity in rural Rwanda. Land Use Policy 20: 186-196.

Reisdorff, I. 1952. Enquêtes foncières au Ruanda. Mimeo.

Republic of Rwanda. 2004. National land policy. Kigali: Republic of Rwanda.

Republic of Rwanda. 2010. National agricultural survey 2008. Kigali: Republic of Rwanda.

Republic of Rwanda. 2019. National land policy. Kigali: Republic of Rwanda.

Reyntjens, F. 1985. Pouvoir et droit au Rwanda: Droit public et évolution politique, 1916-1973. Tervuren: Musée Royal de l'Afrique Centrale.

Sagashya, D. and C. English 2010. Designing and establishing a land administration system for Rwanda: technical and economic analysis. In Innovations in land rights recognition, administration, and governance, eds. K. Deininger, C. Augustinus, S. Enemark, and P. Munro-Faure, 44-67. Washington, DC.: World Bank.

Santos, F., D. Fletschner, and G. Daconto. 2014. Enhancing inclusiveness of Rwanda's land tenure regularization program: Insights from early stages of its implementation. World Development 62: 30-41. https://doi.org/10.1016/j.worlddev.2014.04.011.

Sasaki, K. 1989. Chiso-Kaisei: Kindai nippon heno tochi kaikaku [The land tax reform: A land reform heading for modern Japan]. Tokyo: Chuko Shinsho.

Straus, S. 2006. The order of genocide: Race, power, and war in Rwanda. Ithaca: Cornell University Press.

Takeuchi, S. and J. Marara. 2000. Agriculture and peasants in Rwanda: A preliminary report. Chiba: Institute of Developing Economies.

Takeuchi, S., and J. Marara. 2014. Land tenure security in post-conflict Rwanda. In Confronting land and property problems for peace, ed. Shinichi Takeuchi, 86-108. London: Routledge.

Vansina, J. 2001. Le Rwanda ancient: Le royaume nyiginya. Paris: Karthala.

Open Access This chapter is licensed under the terms of the Creative Commons Attribution 4.0 International License (http://creativecommons.org/licenses/by/4.0/), which permits use, sharing, adaptation, distribution and reproduction in any medium or format, as long as you give appropriate credit to the original author(s) and the source, provide a link to the Creative Commons license and indicate if changes were made.

The images or other third party material in this chapter are included in the chapter's Creative Commons license, unless indicated otherwise in a credit line to the material. If material is not included in the chapter's Creative Commons license and your intended use is not permitted by statutory regulation or exceeds the permitted use, you will need to obtain permission directly from the copyright holder.

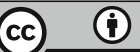

